\title{
Impact of mutational status on survival in low-grade serous carcinoma of the ovary or peritoneum
}

\author{
David M Gershenson ${ }^{\star, 1}$, Charlotte C Sun ${ }^{1}$ and Kwong-Kwok Wong ${ }^{1}$ \\ ${ }^{1}$ Department of Gynecologic Oncology and Reproductive Medicine, The University of Texas MD Anderson Cancer Center, \\ Houston, TX 77030, USA
}

Background: Low-grade serous carcinoma of the ovary or peritoneum is a distinct, well- recognized histologic subtype characterized by young age at diagnosis, relative chemoresistance, and prolonged overall survival. Common mutations reported to be found within this subtype include KRAS and BRAF.

Methods: Using clinical information of patients from our IRB-approved registry and tissue from a subset of these patients, we performed mutational analysis for KRAS and BRAF using the direct Sanger sequencing technique and correlated findings with the clinical outcome, overall survival (OS).

Results: In 79 cases, patients with KRAS or BRAF mutations $(n=21)$ had a significantly better OS than those with wild-type KRAS or $\operatorname{BRAF}(n=58)(106.7$ months $(95 \% \mathrm{Cl}, 50.6,162.9)$ vs 66.8 months $(95 \% \mathrm{Cl}, 43.6,90.0))$, respectively $(P=0.018)$.

Conclusions: Mutational status appears to be a potential prognostic factor in low-grade serous carcinoma of the ovary or peritoneum.

Low-grade serous carcinoma of the ovary or peritoneum is a distinct histologic subtype that may arise either de novo or following a diagnosis of serous tumour of low malignant potential (STLMP) (Crispens et al, 2002; Malpica et al, 2004; Gershenson et al, 2006; Shvartsman et al, 2007; Gershenson et al, 2015). Its clinical behaviour is characterized by young age at diagnosis, relative chemoresistance, and prolonged overall survival (OS) relative to high-grade subtypes of ovarian cancer (Gershenson et al, 2006; Gershenson et al, 2015). In addition, the diagnosis of the de novo presentation most commonly is made in the advanced stages.

In 2003, Singer and colleagues reported that KRAS and BRAF mutations occurred with a frequency of $35 \%$ and $33 \%$, respectively, in low-grade serous carcinoma of the ovary, or what they termed, 'invasive micropapillary serous carcinoma' (Singer et al, 2003). However, subsequent reports indicated a much lower frequency of BRAF mutation in low-grade serous carcinoma (Wong et al, 2010; Grisham et al, 2012; Farley et al, 2013; Tsang et al, 2013). The frequency of KRAS mutations ranged from 16 to 41\% (Wong et al, 2010; Grisham et al, 2012; Farley et al, 2013). These results confirm that low-grade serous carcinoma has a distinct molecular pathway, and that, specifically, the mitogen-activated protein kinase pathway appears to have a major role in the pathogenesis of this subtype. Although the initial clinical trial of a MEK inhibitor, selumetinib, demonstrated promising activity in recurrent low-grade serous carcinoma of the ovary or peritoneum, with an objective response rate of $15 \%$, there was no correlation between response and mutational status (Farley et al, 2013). Subsequent phase III clinical trials studying the activity and toxicity of different MEK inhibitors in recurrent low-grade serous carcinoma are ongoing; these trials include translational research objectives intended to re-test the hypothesis that response to this targeted therapy approach is correlated with activation of the mitogen-activated protein kinase pathway. The purpose of this study was to investigate OS based on KRAS or BRAF mutational status in lowgrade serous carcinoma. 


\section{MATERIALS AND METHODS}

This study was approved by the institutional review board at the University of Texas M.D. Anderson Cancer Center. The LowGrade Serous Tumor Database is a longitudinal database that contains clinico-demographic information from patients who have provided written informed consent in accordance with protocol guidelines. We identified patients with low-grade serous carcinoma of the ovary or peritoneum for whom tumour tissue was available for study. All patients provided written informed consent for use of their tumour specimens. Eligibility criteria for inclusion in this study were: (i) Original diagnosis of advanced stage STLMP with recurrence as metastatic low-grade serous carcinoma or de novo diagnosis of stage II-IV low-grade serous carcinoma; and (ii) adequate clinical information based on completeness of follow-up, date of last contact, and current status. Patients with STLMP without recurrence as low-grade serous carcinoma or those with stage I low-grade serous carcinoma were excluded. Pathology slides of all patients were reviewed by MD Anderson gynaecologic pathologists and documented as low-grade serous carcinoma using criteria that have been previously reported by our group (Malpica et al, 2004; Schmeler et al, 2011). Formalin-fixed, paraffinembedded or frozen tissue blocks were retrieved from the Department of Pathology or the Gynecologic Oncology Tumor Repository, respectively, and MD Anderson gynaecologic pathologists confirmed tissue sections selected for mutational analysis for KRAS and BRAF to contain low-grade serous carcinoma with more than $40 \%$ tumour cells. Following extraction of DNA, direct Sanger sequencing of PCR products was performed as described previously (Wong et al, 2010). Statistical analyses were performed using IBM SPSS version 21 (Armonk, NY, USA). Chi-square test was used to compare the differences in categorical variables between groups. The Fisher's exact test was used when appropriate. Overall survival (OS) times were calculated from the date of confirmed tissue diagnosis for de novo low-grade serous carcinoma patients and from the date of recurrence as low-grade serous carcinoma for the patients with STLMP to the date of last contact or death, respectively. The cumulative distribution of OS was estimated using the method of Kaplan and Meier (Kaplan and Meier, 1958). The log-rank test was used to compare differences between survival curves. The individual effects of age, race, primary site, surgery type, KRAS/BRAF mutation status, residual disease at the completion of surgery, disease status at completion of primary therapy, low-grade serous carcinoma type (recurrent low malignant potential or de novo low-grade), and stage on OS were assessed using Cox proportional hazards regression. Variables with $P$-values $<0.25$ on univariable analysis were included in the multivariable analysis. A $P$-value of $<0.05$ was considered statistically significant.

\section{RESULTS}

Seventy-nine cases that met the eligibility criteria and for whom either formalin-fixed, paraffin-embedded $(n=75)$ or frozen $(n=4)$ tissue were available for mutational analysis were identified. Patients were diagnosed with low-grade serous carcinoma between 1975 and 2009. Patient characteristics are detailed in Table 1. Sixtyfive $(82.3 \%)$ patients had stage II-IV de novo tumour, and 14 $(17.7 \%)$ had metastatic tumour following an original diagnosis of advanced stage STLMP. The primary site of disease was ovary for $66(83.5 \%)$ patients and peritoneum for 13 (16.5\%) patients. Median age at diagnosis was 46 years (range, 21-79 years). Most patients underwent surgery at some point during their clinical course, and most had multiple lines of systemic therapies. The majority of patients underwent primary cytoreductive surgery, had
Table 1. Patient characteristics $(N=79)$

\begin{tabular}{|c|c|c|c|}
\hline & $\begin{array}{l}\text { Wild type } \\
\quad(n=58)\end{array}$ & $\begin{array}{c}\text { BRAF/KRAS } \\
\text { mutation } \\
(n=21)\end{array}$ & $P$-value \\
\hline $\begin{array}{l}\text { Median age, years } \\
\text { (range) }\end{array}$ & $46.3(21.1,79.0)$ & $44.3(26.4,71.5)$ & 0.59 \\
\hline Race & & & 0.11 \\
\hline $\begin{array}{l}\text { White } \\
\text { Black } \\
\text { Other }\end{array}$ & $\begin{array}{c}45(77.6 \%) \\
4(6.9 \%) \\
9(15.5 \%)\end{array}$ & $\begin{array}{c}14(66.7 \%) \\
5(23.8 \%) \\
2(9.5 \%)\end{array}$ & \\
\hline $\begin{array}{l}\text { Year of diagnosis of } \\
\text { LGSC }\end{array}$ & & & 0.21 \\
\hline $\begin{array}{l}1975-1992 \\
1993-2009\end{array}$ & $\begin{array}{l}12(20.7 \%) \\
46(79.3 \%)\end{array}$ & $\begin{array}{c}2(9.5 \%) \\
19(90.5 \%)\end{array}$ & \\
\hline Site & & & 0.08 \\
\hline $\begin{array}{l}\text { Ovary } \\
\text { Peritoneum }\end{array}$ & $\begin{array}{l}46(79.3 \%) \\
12(20.7 \%)\end{array}$ & $\begin{array}{c}20(95.2 \%) \\
1(4.8 \%)\end{array}$ & \\
\hline Stage & & & 0.89 \\
\hline $\begin{array}{l}\text { II } \\
\text { III } \\
\text { IV } \\
\text { STLMP } \rightarrow \text { LGSC }\end{array}$ & $\begin{array}{c}3(5.2 \%) \\
39(67.2 \%) \\
7(12.1 \%) \\
9(15.5 \%)\end{array}$ & $\begin{array}{c}1(4.8 \%) \\
13(61.9 \%) \\
2(9.5 \%) \\
5(23.8 \%)\end{array}$ & \\
\hline Initial surgery & & & 0.91 \\
\hline $\begin{array}{l}\text { Primary CRS } \\
\text { NACT followed by IDS } \\
\text { No surgery }\end{array}$ & $\begin{array}{c}47(81.0 \%) \\
9(15.5 \%) \\
2(3.4 \%)\end{array}$ & $\begin{array}{c}17(81.0 \%) \\
3(14.3 \%) \\
1(4.8 \%)\end{array}$ & \\
\hline $\begin{array}{l}\text { Residual disease at the } \\
\text { completion of surgery }\end{array}$ & & & 0.16 \\
\hline $\begin{array}{l}\text { No gross residual } \\
\text { disease } \\
\text { Gross residual disease } \\
\text { No surgery } \\
\text { Unknown }\end{array}$ & $\begin{array}{l}12(20.7 \%) \\
40(69.0 \%) \\
2(3.4 \%) \\
4(6.9 \%)\end{array}$ & $\begin{array}{c}7(33.3 \%) \\
11(52.4 \%) \\
1(4.8 \%) \\
2(9.5 \%)\end{array}$ & \\
\hline Initial systemic treatment & & & 0.34 \\
\hline $\begin{array}{l}\text { Non-platinum } \\
\text { chemotherapy } \\
\text { Platinum-based } \\
\text { chemotherapy } \\
\text { No chemotherapy } \\
\text { Hormonal treatment }\end{array}$ & $\begin{array}{c}4(6.9 \%) \\
52(89.7 \%) \\
1(1.7 \%) \\
1(1.7 \%)\end{array}$ & $\begin{array}{l}0(0.0 \%) \\
17(81.0 \%) \\
2(9.5 \%) \\
2(9.5 \%) \\
\end{array}$ & \\
\hline $\begin{array}{l}\text { Disease status at } \\
\text { completion of primary } \\
\text { treatment }\end{array}$ & & & 0.79 \\
\hline $\begin{array}{l}\text { No disease } \\
\text { Disease present } \\
\text { No chemotherapy } \\
\text { Unknown }\end{array}$ & $\begin{aligned} 26 & (44.8 \%) \\
30 & (51.7 \%) \\
1 & (1.7 \%) \\
1 & (1.7 \%)\end{aligned}$ & $\begin{array}{l}9(50.0 \%) \\
9(50.0 \%) \\
2(9.5 \%) \\
1(4.8 \%)\end{array}$ & \\
\hline
\end{tabular}

Abbreviations: $C R S=$ cytoreductive surgery; IDS = interval debulking surgery; LGSC = lowgrade serous carcinoma; NACT = neoadjuvant chemotherapy; STLMP = serous tumour of low malignant potential.

${ }^{a}$ Cases of primary cytoreductive surgery and interval debulking surgery were combined for this analysis.

gross residual disease at completion of surgery, and initially received platinum-based chemotherapy. There were no significant differences in characteristics between wild-type and BRAF/KRAS mutation cases except for site (ovary vs peritoneum).

Mutational analysis revealed KRAS mutation (12 G12D, 2 G12V, 2 G12A, 1 G12S, and 1 G12R) in 18 (22.8\%) cases and BRAF V600E mutation in $3(3.8 \%)$ cases, for a total of 21 mutations (26.6\%). No detectable mutations (wild-type) of KRAS or BRAF were identified in $58(73.4 \%)$ cases. The median OS for the entire cohort of 79 patients was 81.3 months (95\% CI, 66.1, 96.4 months). The median OS for women whose tumours contained a KRAS or BRAF mutation was 106.8 months (95\% CI, 50.6, 162.9) compared with 66.8 months (95\% CI, 43.6, 90.0) 


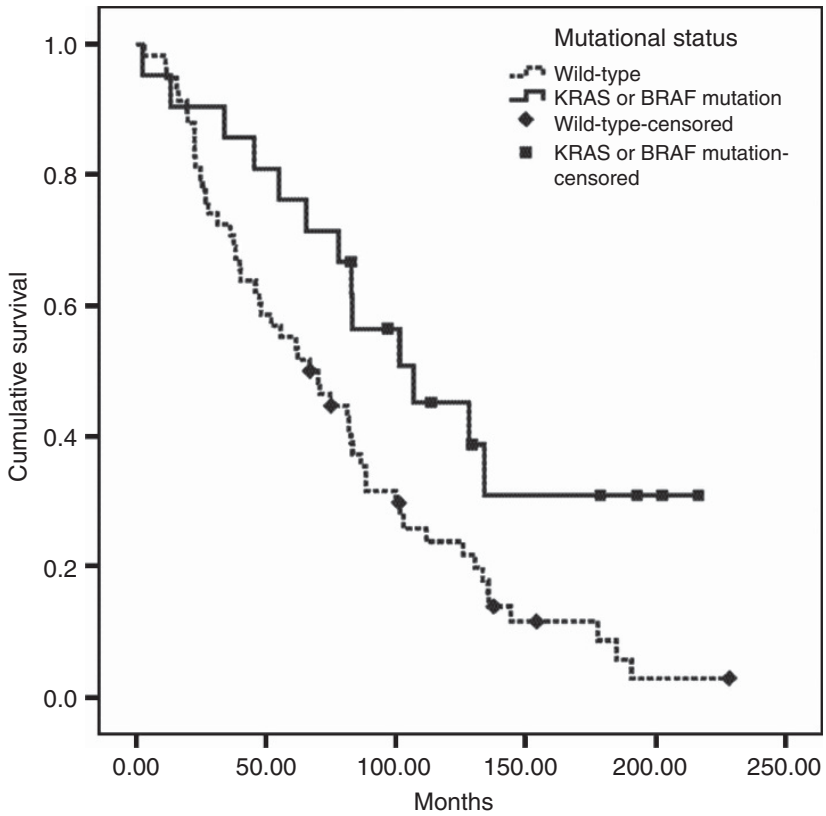

Figure 1. Overall survival. The median OS for women with KRAS or BRAF mutation was 106.8 months $(95 \% \mathrm{Cl}, 50.6,162.9)$ compared with 66.8 months $(95 \% \mathrm{Cl}, 43.6,90.0)$ for women whose tumours contained no KRAS or BRAF mutations $(P=0.018)$. for women whose tumours contained no KRAS or BRAF mutations $(P=0.018)$ (Figure 1$)$.

The results of univariable and multivariable Cox proportional hazards regression are shown in Table 2. Only KRAS/BRAF mutation status, residual disease at the completion of surgery, and disease status at the completion of primary therapy were included in the multivariable analysis. Compared with the wild type, the presence of a KRAS/BRAF mutation conferred a protective effect on OS $(\mathrm{HR}=0.49 ; 95 \%$ CI $(0.26,0.95) ; P=0.03)$. Conversely, compared with no disease at the completion of primary therapy, the presence of persistent disease resulted in compromised OS $(\mathrm{HR}=2.17 ; 95 \% \mathrm{CI}(1.23,3.83) ; P=0.007)$.

\section{DISCUSSION}

Our preliminary results suggest that a KRAS or BRAF mutation may serve as a favourable prognostic factor and have a significant impact on outcome in women with metastatic low-grade serous carcinoma of the ovary or peritoneum. Furthermore, after adjusting for the effects of other variables, the influence of KRAS/BRAF mutational status on OS remained statistically significant. Potential limitations of this study include the traditional method of genomic sequencing and potential selection bias associated with patients seen in a tertiary care centre. In addition, we have combined cases of BRAF and KRAS mutations, not definitely understanding whether the effect of these mutations on

Table 2. Univariable and multivariable Cox proportional hazards for overall survival

\begin{tabular}{|c|c|c|c|c|c|c|}
\hline \multirow[b]{2}{*}{ Variable } & \multicolumn{3}{|c|}{ Univariable } & \multicolumn{3}{|c|}{ Multivariable } \\
\hline & HR & $95 \% \mathrm{Cl}$ & $P$ & HR & $95 \% \mathrm{Cl}$ & $P$ \\
\hline \multicolumn{7}{|l|}{ Primary site } \\
\hline $\begin{array}{l}\text { Ovary (reference) } \\
\text { Peritoneal }\end{array}$ & $\overline{0.98}$ & $0.51,1.88$ & $0 . \overline{95}$ & & & \\
\hline Age, years & 1.00 & $0.98,1.02$ & 0.81 & & & \\
\hline \multicolumn{7}{|l|}{ Race } \\
\hline $\begin{array}{l}\text { White (reference) } \\
\text { Non-white }\end{array}$ & $\overline{1.14}$ & $0.59,2.26$ & $0 . \overline{69}$ & & & \\
\hline Surgery type & & & 0.37 & & & \\
\hline $\begin{array}{l}\text { Primary CRS (reference) } \\
\text { NACT followed by IDS } \\
\text { No surgery }\end{array}$ & $\begin{array}{l}\overline{0} \\
0.38\end{array}$ & $\begin{array}{c}-\overline{-} \\
0.41,1.71 \\
0.09,1.55\end{array}$ & $\begin{array}{l}0 . \overline{64} \\
0.18\end{array}$ & & & \\
\hline \multicolumn{7}{|l|}{ KRAS/BRAF mutation status } \\
\hline $\begin{array}{l}\text { Wild type (reference) } \\
\text { KRAS/BRAF mutation }\end{array}$ & $\overline{0.48}$ & $0 . \overline{26,0.89}$ & $0 . \overline{02}$ & $\overline{0.49}$ & $0 . \overline{26,0.95}$ & $0 . \overline{03}$ \\
\hline Residual disease at completion of surgery & & & 0.03 & & & 0.26 \\
\hline $\begin{array}{l}\text { No gross residual disease (reference) } \\
\text { Gross residual disease } \\
\text { No surgery } \\
\text { Unknown }\end{array}$ & $\begin{array}{l}\overline{-} .41 \\
0.71 \\
1.57\end{array}$ & $\begin{array}{l}1.26,4.60 \\
0.16,3.20 \\
0.50,4.96\end{array}$ & $\begin{array}{l}0 . \overline{008} \\
0.65 \\
0.44\end{array}$ & $\begin{array}{l}\overline{1.53} \\
0.46 \\
1.06\end{array}$ & $\begin{array}{l}-\overline{-} \\
0.74,3.16 \\
0.10,2.15 \\
0.32,3.51\end{array}$ & $\begin{array}{l}0 . \overline{25} \\
0.32 \\
0.92\end{array}$ \\
\hline $\begin{array}{l}\text { Disease status at completion of primary } \\
\text { therapy }\end{array}$ & & & 0.002 & & & 0.03 \\
\hline $\begin{array}{l}\text { No disease (reference) } \\
\text { Disease present } \\
\text { No chemotherapy }\end{array}$ & $\begin{array}{l}\overline{2.46} \\
0.68\end{array}$ & $\begin{array}{c}-\overline{-} \\
1.44,4.22 \\
0.16,2.89\end{array}$ & $\begin{array}{l}0 . \overline{0} 1 \\
0.60\end{array}$ & $\begin{array}{l}\overline{2.17} \\
1.03\end{array}$ & $\begin{array}{c}-\overline{-} \\
1.23,3.83 \\
0.23,4.63\end{array}$ & $\begin{array}{l}0 . \overline{007} \\
0.97\end{array}$ \\
\hline Stage & & & 0.88 & & & \\
\hline $\begin{array}{l}\text { II (reference) } \\
\text { III/IV } \\
\text { STLMP } \rightarrow \text { LGSC }\end{array}$ & $\begin{array}{l}\overline{1.31} \\
1.21\end{array}$ & $\begin{array}{c}-\overline{-} \\
0.41,4.25 \\
0.39,4.35\end{array}$ & $\begin{array}{l}0 . \overline{65} \\
0.77\end{array}$ & & & \\
\hline \multicolumn{7}{|l|}{ LGSC type } \\
\hline $\begin{array}{l}\text { Recurrent LMP (reference) } \\
\text { de novo LGSC }\end{array}$ & $\overline{1.07}$ & $0.57,2.00$ & $0 . \overline{84}$ & & & \\
\hline
\end{tabular}


outcome is similar. We have done so because there are only three cases with BRAF mutation, but future studies of larger cohorts will hopefully further illuminate this issue. Future investigations need to include more sensitive next-generation sequencing techniques, interrogation of other gene mutations, such as NRAS, and a larger number of patients with comparable long follow-up times. For example, Emmanuel et al (2014) found NRAS mutations in 9\% of invasive serous carcinomas with adjacent STLMP. In addition, if our findings are confirmed, combined with future data on the activity of targeted therapies in low-grade serous carcinoma in the context of their molecular profile, this information may allow greater individualization of treatment.

In contrast to the findings of this study, several reports have suggested the association of KRAS or BRAF mutations with poorer outcome compared with wild-type KRAS or BRAF in a variety of malignancies (Andreyev et al, 2001; Souglakos et al, 2009; Johnson et al, 2012). The explanation for this potential discordance is unclear. The ability of oncogenes to induce senescence in normal cells and premalignant tumours is well established (Dhomen et al, 2009; Collado and Serrano, 2010; Vicent et al, 2010). In addition, when wild-type p53 is reactivated in a mouse hepatocellular carcinoma induced by oncogenic ras and knockdown of p53, tumours cells undergo senescence and activation of the immune system. In one report, immune cells rapidly cleared senescent tumour cells to prevent further progression or even resulted in regression (Xue et al, 2007). As most low-grade ovarian serous cancer cells have wild-type $\mathrm{p} 53$, it is possible that this subtype with a KRAS mutation may have senescent tumour cells that are cleared by immune cells, thereby inhibiting tumour progression. However, further investigation to elucidate this potential mechanism is required.

Although low-grade serous carcinoma is associated with superior survival outcomes compared with high-grade serous carcinoma and other high-grade ovarian cancers, such as clear cell and highgrade endometrioid subtypes, nevertheless, over $70 \%$ of women with low-grade serous carcinoma relapse and ultimately succumb to their cancer. Thus, it is important that we continue to concentrate on better understanding the biology of this rare subtype while concomitantly working toward improving treatment.

\section{ACKNOWLEDGEMENTS}

Funding: This work was supported in part by The National Cancer Institute at the National Institutes of Health (P50 CA83639 to DMG and KKW), National Institutes of Health through Cancer Center Support Grant (P30 CA016672 to DMG, CCS, and KKW), and The Sara Brown Musselman Fund for Serous Ovarian Cancer Research (DMG, CCS, and KKW).

\section{CONFLICT OF INTEREST}

The authors declare no conflict of interest.

\section{REFERENCES}

Andreyev HJ, Norman AR, Cunningham D, Oates J, Dix BR, Iacopetta BJ, Young J, Walsh T, Ward R, Hawkins N, Beranek M, Jandik P, Benamouzig R, Jullian E, Laurent-Puig P, Olschwang S, Muller O, Hoffmann I, Rabes HM, Zietz C, Troungos C, Valavanis C, Yuen ST, Ho JW, Croke CT, O’Donoghue DP, Giaretti W, Rapallo A, Russo A, Bazan V, Tanaka M, Omura K, Azuma T, Ohkusa T, Fujimori T, Ono Y, Pauly M, Faber C, Glaesener R, de Goeij AF, Arends JW, Andersen SN, Lövig T, Breivik J, Gaudernack G, Clausen OP, De Angelis PD, Meling GI, Rognum TO, Smith R, Goh HS, Font A, Rosell R, Sun XF, Zhang H, Benhattar J, Losi L, Lee JQ, Wang ST, Clarke PA, Bell S, Quirke P, Bubb VJ, Piris J,
Cruickshank NR, Morton D, Fox JC, Al-Mulla F, Lees N, Hall CN, Snary D, Wilkinson K, Dillon D, Costa J, Pricolo VE, Finkelstein SD, Thebo JS, Senagore AJ, Halter SA, Wadler S, Malik S, Krtolica K, Urosevic N (2001) Kirsten ras mutations in patients with colorectal cancer: the 'RASCAL II' study. Br J Cancer 85: 692-696.

Collado M, Serrano M (2010) Senescence in tumours: evidence from mice and humans. Nat Rev Cancer 10: 51-57.

Crispens MA, Bodurka D, Deavers M, Lu K, Silva EG, Gershenson DM (2002) Response and survival in patients with progressive or recurrent serous ovarian tumors of low malignant potential. Obstet Gynecol 99: $3-10$.

Dhomen N, Reis-Filho JS, da Rocha Dias S, Hayward R, Savage K, Delmas V, Larue L, Pritchard C, Marais R (2009) Oncogenic Braf induces melanocyte senescence and melanoma in mice. Cancer Cell 15: 294-303.

Emmanuel C, Chiew Y-E, George J, Etemadmoghadam D, Sharma R, Russell P, Kennedy C, Fereday S, Hung J, Galletta L, Hogg R, Wain GV, Brand A, Balleine R, Anglesio MS, MacConaill LE, Palescandolo E, Hunter SM, Campbell I, Dobrovic A, Wong SQ, Do H, Clarke CL, Harnett PR, Bowtell DD, deFazio A. Australian Ovarian Cancer Study (AOCS) (2014) Genomic classification of serous ovarian cancer with adjacent borderline differentiates RAS-pathway and TP53-mutant tumors and identifies NRAS as an oncogenic driver. Clin Cancer Res 20(24): 6618-6630.

Farley J, Brady WE, Vathipadiekal V, Lankes HA, Coleman R, Morgan MA, Mannel R, Yamada SD, Mutch D, Rodgers WH, Birrer M, Gershenson DM (2013) Selumetinib in women with recurrent low-grade serous carcinoma of the ovary or peritoneum: an open-label, single-arm, phase 2 study. Lancet Oncol 14: 134-140.

Gershenson DM, Sun CC, Lu KH, Coleman RL, Sood AK, Malpica A, Deavers MT, Silva EG, Bodurka DC (2006) Clinical behavior of stage II-IV low-grade serous carcinoma of the ovary. Obstet Gynecol 108: 361-368.

Gershenson DM, Bodurka D, Lu K, Nathan LC, Milojevic L, Wong KK, Malpica A, Sun CC (2015) The impact of age and primary disease site on outcome of women with low-grade serous carcinoma of the ovary or peritoneum: Results of a large single-institution registry of a rare tumor. J Clin Oncol 33: 2675-2682.

Grisham RN, Iyer G, Garg K, DeLair D, Hyman DM, Zhou Q, Iasonos A, Berger MF, Dao F, Spriggs DR, Levine DA, Aghajanian C, Solit DB (2012) BRAF Mutation is associated with early stage disease and improved outcome in patients with low-grade serous ovarian cancer. Cancer 119: 548-554.

Johnson ML, Sima CS, Chaft J, Paik PK, Pao W, Kris MG, Ladanyi M, Riely GJ (2012) Association of KRAS and EGFR mutations with survival in patients with advanced lung adenocarcinomas. Cancer 119: 356-362.

Kaplan EL, Meier P (1958) Nonparametric estimation from incomplete observations. J Am Stat Assoc 53: 457-481.

Malpica A, Deavers MT, Lu K, Bodurka DC, Atkinson EN, Gershenson DM, Silva EG (2004) Grading ovarian serous carcinoma using a two-tier system. Am J Surg Pathol 28: 496-504.

Schmeler KM, Sun CC, Malpica A, Deavers MT, Bodurka DC, Gershenson DM (2011) Low-grade serous primary peritoneal carcinoma. Gynecol Oncol 121: 482-486.

Shvartsman HS, Sun CC, Bodurka DC, Mahajan V, Crispens M, Lu KH, Deavers MT, Malpica A, Silva EG, Gershenson DM (2007) Comparison of the clinical behavior of newly diagnosed stages II-IV low-grade serous carcinoma of the ovary with that of serous ovarian tumors of low malignant potential that recur as low-grade serous carcinoma. Gynecol Oncol 105: 625-629.

Singer G, Oldt R, Cohen Y, Wang BG, Sidransky D, Kurman RJ, Shih I-M (2003) Mutations in BRAF and KRAS characterize the development of low-grade ovarian serous carcinoma. J Natl Cancer Inst 95: $484-486$.

Souglakos J, Philips J, Wang R, Marwah S, Silver M, Tzardi M, Silver J, Ogino S, Hooshmand S, Kwak E, Freed E, Meyerhardt JA, Saridaki Z, Georgoulias V, Finkelstein D, Fuchs CS, Kulke MH, Shivdasani RA (2009) Prognostic and predictive value of common mutations for treatment response and survival in patients with metastatic colorectal cancer. Br J Cancer 101: 465-472.

Tsang YT, Deavers MT, Sun CC, Kwan S-Y, Kuo E, Malpica A, Mok SC, Gershenson DM, Wong K-K (2013) KRAS (but not BRAF) mutations in 
ovarian serous borderline tumour are associated with recurrent low-grade serous carcinoma. J Pathol 231: 449-456.

Vicent S, Chen R, Sayles LC, Lin C, Walker RG, Gillespie AK, Subramanian A, Hinkle G, Yang X, Saif S, Root DE, Huff V, Hahn WC, Sweet-Cordero EA (2010) Wilms tumor 1 (WT1) regulates KRAS-driven oncogenesis and senescence in mouse and human models. J Clin Invest 120: $3940-3952$.
Wong K-K, Tsang YT, Deavers MT, Mok SC, Zu Z, Sun C, Malpica A, Wolf JK, Lu KH, Gershenson DM (2010) BRAF mutation is rare in advanced-stage low-grade ovarian serous carcinomas. Am J Pathol 177: 1611-1617.

Xue W, Zender L, Miething C, Dickins RA, Hernando E, Krizhanovsky V, Cordon-Cardo C, Lowe SW (2007) Senescence and tumour clearance is triggered by p 53 restoration in murine liver carcinomas. Nature $\mathbf{4 4 5}$ : 656-660. 